\title{
Studies on Sugar Diffusion From Sugarcane Storage Tissue ${ }^{1}$
}

\author{
Nilsa Acin-Draz and Alex G. Alexander ${ }^{2}$
}

INTRODUCTION

To account for solute movement across an impermeable membrane, two hypotheses have been widely examined: ${ }^{3}$ (a) Passive diffusion by the transient molecule, made possible by special physicochemical properties of the membrane, and (b) active entry of molecules into the cell by virtue of biochemical reactions occurring at the cell surface.

During the early 1960 's, Bieleski $(2,3,4)$ found that sugarcane storage tissues take up sugars in two stages. The initial uptake reaches equilibrium within 1 hour, is proportional to the external sugar concentration, is unaffected by anaerobic conditions, and is completely reversed when the tissue is placed in water. The secondary uptake continues at a constant rate up to 60 hours, is independent of external sugar concentrations exceeding 0.2 percent, is inhibited by anaerobic conditions, and there is no sugar diffusion when the tissue is placed in water. Bieleski concluded that the first process is nonmetabolic or diffusional and occurs in a portion of the tissue termed the "apparent free space." The second stage of uptake accumulates sugars in the "inner space" via an active, metabolically dependent process. During the decade following Bieleski's work a cyclic mechanism of sugar accumulation in sugarcane storage tissue was discovered and elaborated by Glasziou and his colleagues in Queensland $(11,13,14,17,18,19)$.

As details of the sugar accumulation cycle were elaborated, the diffusion of sugars or of sugar-carrier complexes assumed increasing importance. By 1961 Glasziou (12) had established the spatial separation of three distinct compartments in storage parenchyma tissue: (a) The outer space (including cell walls), (b) the metabolic compartment (including the cytoplasm), and (c) the inner space (or storage vacuole). Early data (11) indicated that sugar passed between outer space and inner space in accordance with the following reaction sequence:

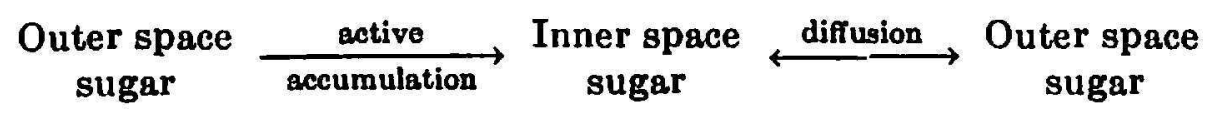

In 1965, additional importance was attached to the sucrose content of

1 Manuscript submitted to the Editorial Board October 4, 1971.

- Research Assistant and Plant Physiologist, respectively, Agricultural Experiment Station, Mayagüez Campus, University of Puerto Rico, Río Piedras, P.R.

s Reviewed by Höber (24). 
discrete intercellular spaces when Hawker (21) found that outer space sucrose levels can nearly equal the vacuolar sucrose content. Positioned mainly in the water phase of cell walls and the intercellular space of the metabolic compartment, Hawker concluded that the intercellular movement of sucrose may proceed by diffusion along the cell walls. Hawker's data were later verified by Glasziou and Gayler (15), who further suggested that the diffusive movement applied only to mature tissue. Sucrose was therefore seen to move by independent processes of active accumulation and diffusion, the relative importance of the two processes being determined by current levels of cell wall acid invertase and neutral invertase, i.e., the enzymes presumably governing the rate of active accumulation.

The existence of abundant diffusible sugar or potentially diffusible sugar in cane storage tissue is an increasingly important consideration. Conventional cane quality measurements utilizing milled juice are empirical; they do not distinguish between stored sucrose and sucrose unretained by barrier membranes. Quality losses during harvest and postharvest operations have not been examined in the light of sugar diffusion from mechanically injured stalks, or of diffusion made possible by operational injury to the sugar accumulation cycle. For the agronomist, therefore, discrepancies in cane quality data ordinarily attributed to cultural, ecological, or varietal variables might have an added basis in the passive diffusion potential. With these considerations in mind, initial studies were performed to evaluate the magnitude and characteristic features of sugar diffusion from cane storage tissue.

\section{MATERIALS AND METHODS}

Field-grown sugarcane of the interspecific variety P.R. 980 was obtained from the Solis Farm at Rio Piedras. Other plants of the same variety were propagated in the greenhouse using a sand-culture technique with controlled nitrogen and water regimes. Full-length stalks were stripped of dead leaves, "high-topped" (retaining about a third of the green-leaf tissue), and immersed in water for transport to the laboratory. All stalk samples were recut under water and maintained standing in water while awaiting tissue preparation.

\section{PREPARATION OF MATURE STALK TISSUE}

Two of three joints of intermediate maturity, i.e., fully elongated and no longer subtended by leaf blades and sheaths, were selected from each stalk. Nodal tissue was discarded. The internodes were washed in tap water and cut into 1-inch segments. The rind, including all chlorophyll-bearing tissues and hard outer sclerenchyma, was removed and each segment divided into four or six wedges, depending on the size of the joint sampled. The tissue wedges were rinsed in tap water to remove debris produced by cutting 
operations and then washed for ten minutes in running tap water with sufficient force to keep the segments in continual motion. The segments were rinsed afterward in distilled water, blotted to remove excess moisture, and weighed for treatment in 20 -g. batches.

\section{PREPARATION OF IMMATURE STALK TISSUE}

One or two expanding internodes, i.e., internodes having achieved about $1 / 2$ to $3 / 4$ of their ultimate length, were selected from each stalk. The procedure followed was the same as for mature tissue with the exception that after rinsing with distilled water the segments were immersed for 5 minutes in $0.02 \mathrm{M}$ ascorbic acid to arrest polyphenol oxidase action.

\section{INCUBATION PROCEDURE}

During the course of the study cane tissue preparations were incubated in water, buffers, and aqueous solutions of various chemical additives. One-hundred $\mathrm{ml}$. of the chosen bathing media were prechilled to about $1^{\circ} \mathrm{C}$. in $250 \mathrm{ml}$. Erlenmeyer flasks. Weighed tissue samples were placed in the solutions and incubated in the refrigerator for 1 hour at $4^{\circ}-6^{\circ} \mathrm{C}$. They were subsequently transferred to fresh solutions kept at room temperature, mixed briefly, and 5-ml. samples of the bathing media were withdrawn from duplicate flasks. These constituted the "zero-time" samples. The flasks were agitated with a mechanical shaker to assure constant mixing of tissue and solution. Additional samples were withdrawn at appropriate intervals. All experiments were performed at room temperature $\left(22^{\circ}-\right.$ $24^{\circ} \mathrm{C}$.).

\section{SUGAR ANALYSES}

For every diffusion experiment, the total sugar content of tissue preparations was determined with 20 -g. samples homogenized with a Waring blendor in $100 \mathrm{ml}$. of distilled water. Tissue debris was removed by expressing the mixture through four layers of absorbent gauze and centrifuging for 10 minutes at 2,500 r.p.m. Total ketoses were measured colorimetrically by the resorcinol method of Roe (26), and sucrose by the modification of Cardini et al. (7). Total reducing sugars were estimated by the dinitrosalicylic-acid technique of Sumner (29). Samples of the bathing media were similarly analyzed following clarification in the centrifuge. Values for diffused sugars were computed as mg. per $\mathrm{g}$. of bathing tissue, or as a percentage of the total sugar in storage at zero time.

\section{RESULTS}

\section{SUGAR DIFFUSION FROM MATURE TISSUE SLICDS}

Sugar diffusion, as evidenced by increased sugar contents of the respective bathing media, was generally rapid and readily detectable by conven- 
tional analytical methods. No evidence of microbial development was found in media standing up to $\mathbf{4 8}$ hours. This observation is consistent with Bieleski (2) who attributed the absence of microbe populations to an endogenous antibiotic property of the cane tissue preparations.

When mature tissue slices were bathed in water, sucrose diffused rapidly for about 4 hours and then more slowly, reaching an equilibrium between 8 and 16 hours (fig. 1). Approximately 50 percent of the sucrose found in the bathing medium at equilibrium exited during the first 2 hours, and virtually all of the external sugar is thought to have originated in the tissue's outer space. Although considerable variation was found between different batches of tissue, the maximum sucrose level in the external medium usually amounted to some 3 to 4 percent of the tissue's sucrose. Most tissue batches showed a small decrease in the concentration of diffused sucrose after 16

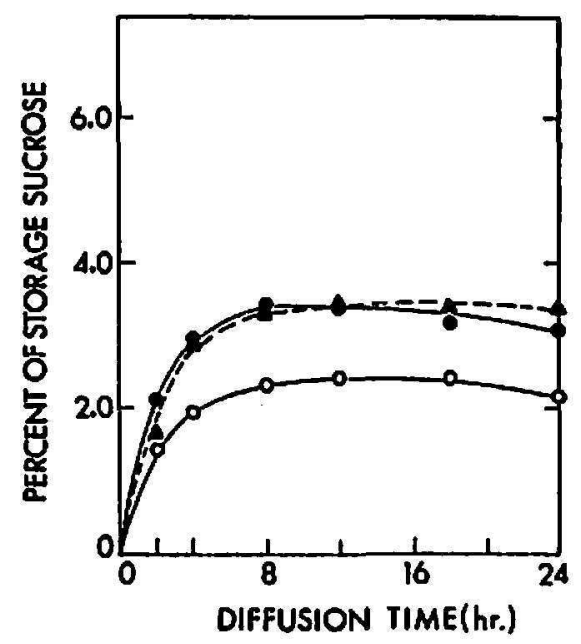

F1a. 1.-Sucrose diffusion from mature storage tissue slices bathed in distilled water. Different curves represent separate experiments. Incubation procedure is described under MATERIALS AND METHODS.

hours. Some evidence has been reported (5) of invertase diffusing from leaf mesophyll to an external solution; however, inversion per se does not account for the present sucrose losses owing to the very small amounts of reducing sugar found in the bathing media. Rather, sucrose is believed to have recntered the tissues by means of the sugar accumulation mechanism.

The magnitude of diffused sucrose usually approached the order of 4.0 $\mathrm{mg}$./g. of tissue (fig. $2, \mathrm{~A}$ ), or some 2.0 to 3.0 percent of the total sucrose in storage by 12 hours. Since the total storage sucrose included vacuolar sugar, i.e., inner space sugar retained behind a barrier membrane by an active accumulation process, the values shown in figure 2 represent a much higher percentage of the outer space sucrose subject to diffusion toward the external medium. In mature storage tissue, sucrose diffusion rates were essentially comparable in Tris buffer ( $\mathrm{pH} 7.8,0.05 \mathrm{M}$ ) and distilled water (fig. 2, B). 
Reducing sugars appeared in the bathing media quite slowly and in relatively small quantities (table 1). Typically, in 24 hours a total hexose value of 0.20 to $0.30 \mathrm{mg}$./g. of tissue was detected, less than $1 / 10$ of that obtained for sucrose.

\section{SUGAR DIFFUSION FROM IMMATURE TISSUE SLICES}

Exiting over a time course of about 8 hours, the movement of sucrose from immature storage tissue into distilled water was of generally lesser

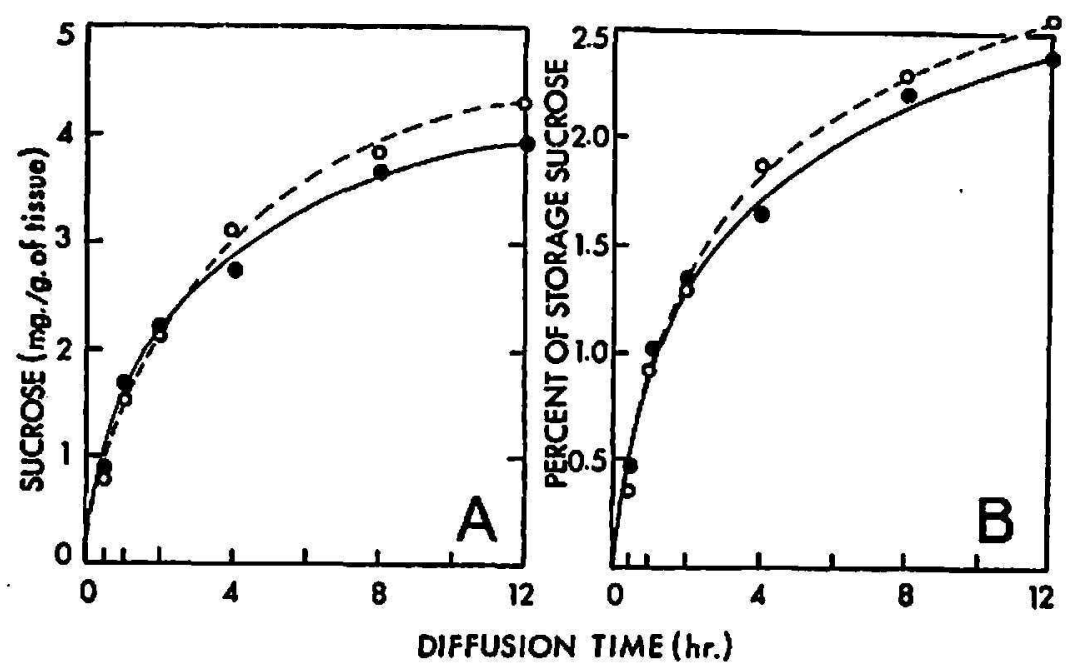

Fig. 2.-Typical sucrose diffusion curves over a time-course of 12 hours for mature storage tissue bathed in distilled water and Tris buffer (pH 7.0, 0.05 M). A, Diffusion expressed as $\mathrm{mg}$. per $\mathrm{g}$. of tissue; $\mathrm{B}$, as percent of the tissue's total sucrose content Symbols: (๑) Distilled water; (O) Tris buffer.

TABLE 1.-Reducing sugar diffusion from immalurc slorage tissue slices balhed in distilled water ${ }^{1}$

\begin{tabular}{ccccccc}
\hline \multicolumn{7}{c}{ Reducing sugars (mg./g. of tissue) at bour } \\
\hline 0 & 2 & 4 & 8 & 12 & 18 & 24 \\
\hline 0 & 0.01 & 0.16 & 0.18 & 0.16 & 0.07 & 0.07 \\
\hline
\end{tabular}

1 Mean values for duplicate flasks.

magnitude than was obtained with mature tissue (fig. 3). With Tris buffer serving as the bathing medium a greater flow of sucrose emanated from the immature tissue, particularly during the first hour (table 2). Sucrose began to disappear from the external solution between 8 and 12 hours, and by 24 hours a large portion of the diffused sucrose was lost from the bathing medium (fig. 3). At all sampling periods the sucrose concentration in the bathing solution was greater for mature tissue than for immature tissue.

In general, only small amounts of reducing sugar were found in the solutions bathing immature storage tissue. On the other hand, these quantities represented a relatively large percentage of the tissue's total hexose (fig. 4). 
In those instances where the reducing sugar levels were sufficient for accurate measurement, they were found to increase rapidly for about 2 hours. After 8 to 12 hours this accounted for some 15 to 25 percent of the stored hexose, i.e., in the order of 0.15 to $0.20 \mathrm{mg}$. $/ \mathrm{g}$. of tissue. This was true both in water and Tris buffer, with the sugar concentration beind highest in the former (fig. 4). Reducing sugar tended to decline in the bathing medium after about 12 hours (table 2).

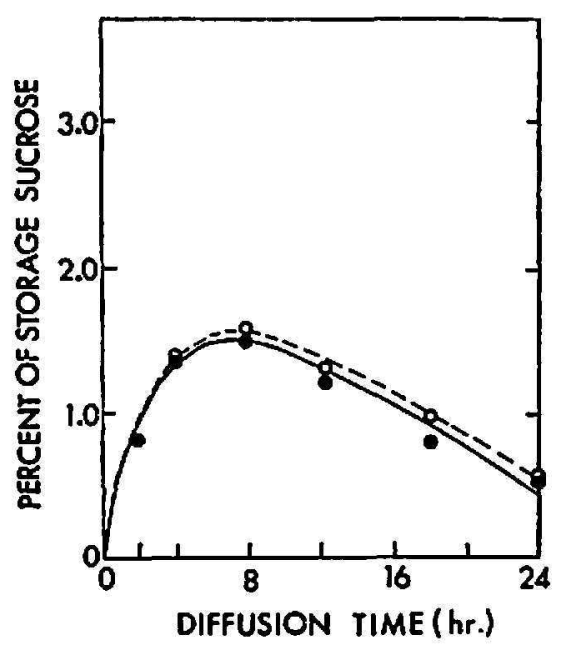

FIg. 3.-Sucrose diffusion from immature storage tissue slices bathed in distilled water. Different curves represent separate experiments. Incubation procedure is described under MATERIALS AND METHODS.

TABLl: 2.-Sucrose diffusion from immalure slorage lissue slices balhed in distilled waler and Tris buffer ${ }^{1}$

\begin{tabular}{lcccccc}
\hline \multirow{2}{*}{ Bathing medium } & \multicolumn{6}{c}{ Percent of total sucrose at hour- } \\
\cline { 2 - 7 } & 0 & $3 / 2$ & 1 & 2 & 4 & 8 \\
\hline Distilled water & 0 & 0.25 & 0.35 & 0.75 & 1.20 & 1.70 \\
Tris buffer $(0.05 \mathrm{M})$ & 0 & 0.67 & 0.95 & 1.10 & 1.60 & 2.00 \\
\hline
\end{tabular}

1 Mean values for duplicate flasks.

\section{FIELD- VS. GREENHOUSE-PROPAGATED TISSUE}

Sucrose diffusion for mature tissue grown in the greenhouse generally conformed to field tissue in rate and magnitude of efflux (fig. 5, A). Immature tissue from the greenhouse showed a smaller maximum efflux and earlier loss of the diffused sugar than did its counterpart propagated in the field (fig. 5, B). For each tissue source the rate of diffusion was initially rapid and achieved a maximum sucrose level in the external medium at about 8 hours. Sucrose subsequently declined in the bathing medium regardless of tissue source. 


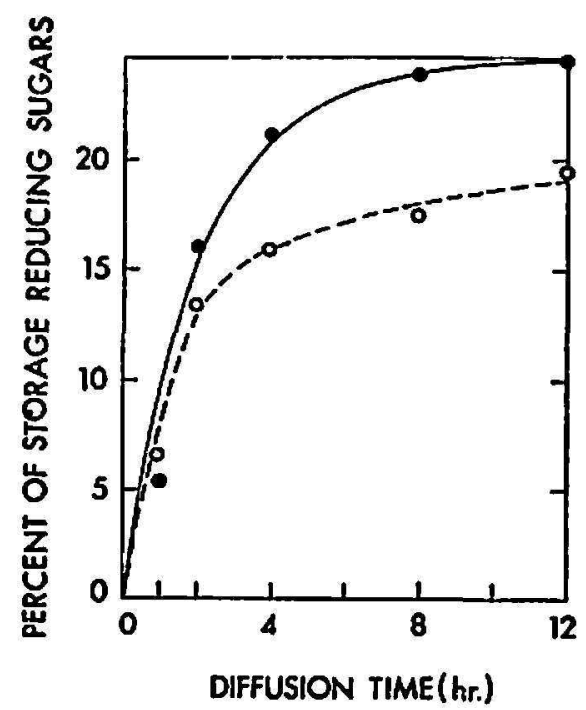

Fra. 4.-Reducing sugar diffusion from immature storage tissue slices bathed in different media over a time-course of 12 hours. Symbols: (๑) Distilled water; (O) Tris buffer ( $\mathrm{pH} 7.0,0.05 \mathrm{M}$ ). Incubation procedure is described under MATERIALS AND METHODS.

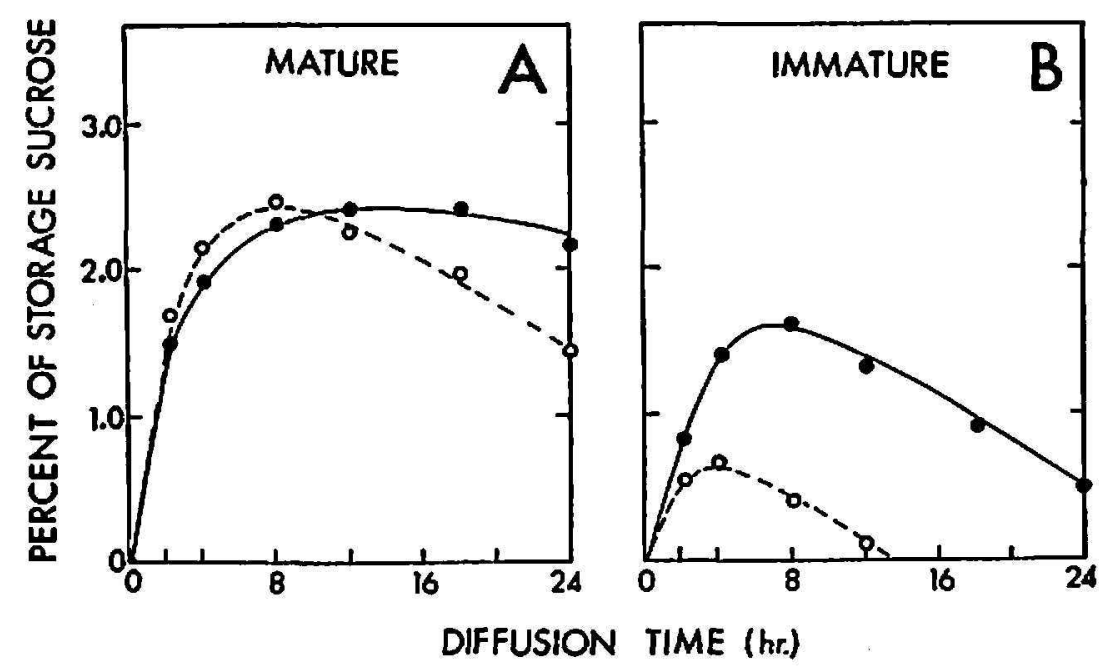

Fıg. 5. Sucrose diffusion from mature and immature storage tissues having different propagative origins. A, Mature tissue; B, immature tissue. Symbols: (0) Field cane; $(O)$ greenhouse cane. The bathing medium was distilled water.

\section{DIFFUSION RESPONSES TO CHEMICAL ADDITIVES}

Various chemical agents, including actinomycin D, DNP (2,4-dinitrophenol), 6-methyl purine, cycloheximide, and boron (boric acid) were examined as bathing-media additives in preliminary experiments designed to clarify the mechanism of sugar diffusion. Actinomycin D produced only slight changes in the initial rate of sucrose movement from mature storage tissue (table 3). Subsequent batches bathed up to 40 hours showed no appreciable effect of actinomycin $D$ on efflux rate or the shape of diffusion curves. This suggests that protein synthesis is not a critical factor in the movement 
of sugar from the outer space. On the other hand, when mature tissue slices were placed in a $2.0 \times 10^{-3} \mathrm{M}$ solution of DNP, sucrose diffusion during the first 4 hours experienced a 5 - to 10 -fold increase over the rates obtained in water (table 3). Sucrose efflux from DNP-treated tissue amounted to some 20 to 30 percent of the toal storage sucrose by the eighth hour. A similar response was obtained for reducing sugars present in the tissue slices.

Inclusion of 6-methyl purine or cycloheximide in the bathing medium caused little change in the initial rates of sucrose diffusion, i.e., up to about the fourth hour (fig. 6). However, subsequent stages of the diffusion process were markedly affected by cycloheximide, and to a lesser degree by 6 -methyl purine. Cycloheximide produced a continuous efflux of sucrose to the external medium at a time when sucrose was ordinarily being lost from the medium. A general status quo was maintained by 6 -methyl purine; that is,

TABLE 3.-Effects of actinomycin D and 2,4-dinitrophenol on the initial rates of sucrose diffusion from malure sugarcane slorage tissue ${ }^{1}$

\begin{tabular}{clrrr}
\hline \multirow{2}{*}{$\begin{array}{c}\text { Experiment } \\
\text { Number }\end{array}$} & \multicolumn{1}{c}{ Bathing solution } & \multicolumn{3}{c}{ Percent of total storage sucrose at hour- } \\
\cline { 3 - 5 } & & 0 & 2 & 4 \\
\hline \multirow{2}{*}{1} & Distilled water & 0 & 1.7 & 3.1 \\
2 & Actinomycin D (0.002\%) & 0 & 1.6 & 2.9 \\
& Actinomycin D (0.008\%) & 0 & 1.3 & 2.3 \\
3 & DNP (0.002 M) & 0 & 12.3 & 23.2 \\
4 & DNP (0.002 M) & 0 & 8.5 & 15.0 \\
\hline
\end{tabular}

1 Mean values for duplicate flasks.

sucrose was not appreciably gained or lost in the bathing solution after the initial efflux rate had subsided. Although these trends were consistent among mature and immature storage tissue propagated both in the field (figs. 6, $\mathrm{A} \& \mathrm{~B}$ ) and greenhouse (figs. 6, $\mathrm{C} \& \mathrm{D}$ ), they were far more pronounced in immature tissue from both sources.

Borate, over a wide range of concentrations, produced moderate but persistent shifts in the rate of sucrose efflux without altering the shape of diffusion curves (table 4). These changes usually appeared as increases over the rates obtained in distilled water during the first 12 hours. Both the broad concentration range affecting diffusion (between $5 \times 10^{-7} \mathrm{M}$ and $5 \times 10^{-3} \mathrm{M}$ boric acid), and the relatively small magnitude of sugar change, suggest a non-enzymic role of borate which affects only the passive movement of outer space sugar.

\section{DISCUSSION}

Several tentative conclusions can be drawn from the present data: (a) Initial sugar diffusion rates are of sufficient magnitude to assume major 
FIELD

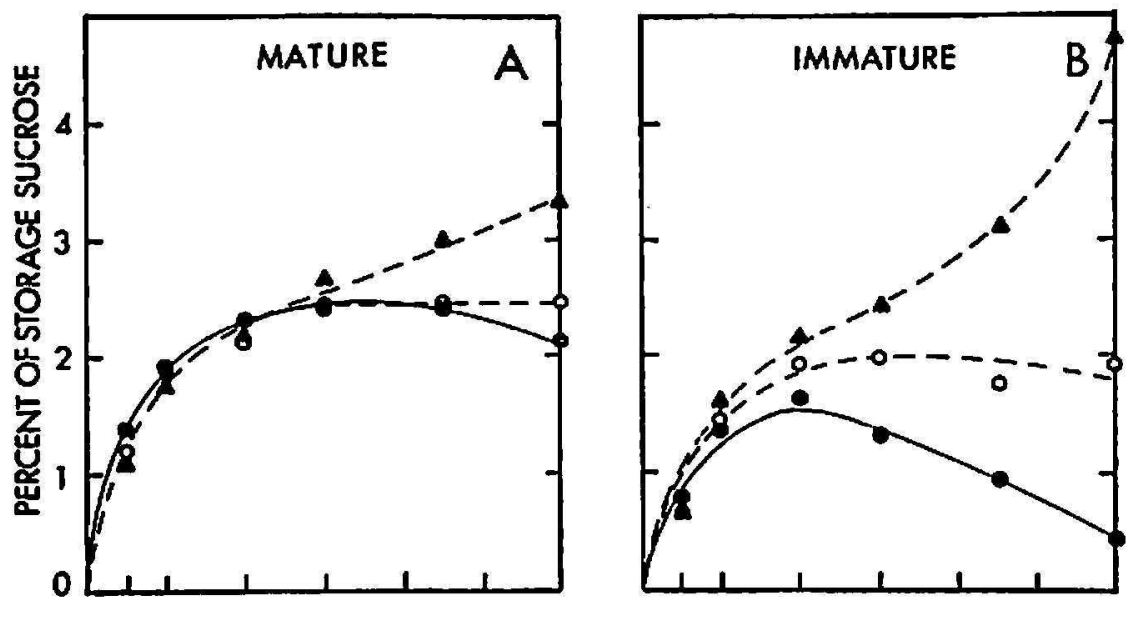

GREENHOUSE

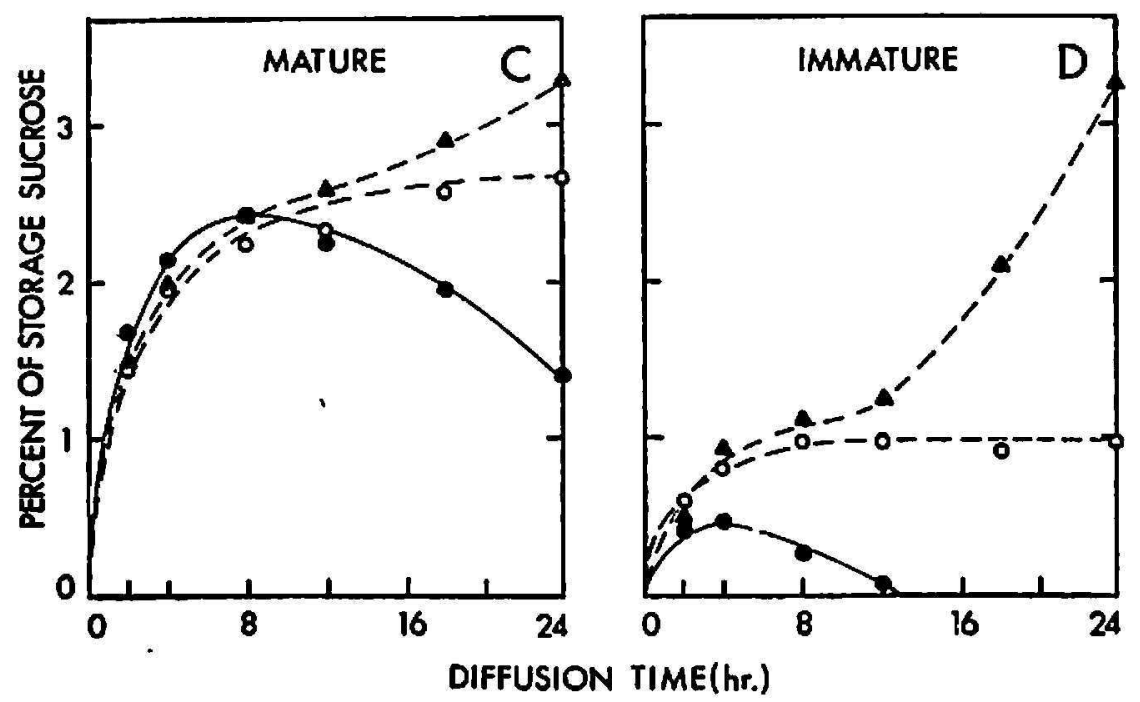

Fig. 6.-Effects of 6-methyl purine and cycloheximide on sucrose diffusion from storage tissues having different maturity and propagative origins. Symbols: (๑) Distilled water; (O) 6-methyl purine; (A) cycloheximide. Top: Field cane; bottom: greenhouse cane.

physiological (and possible economic) significance; (b) the diffusion process appears to operate in conjunction with the active accumulation system established by earlier workers in Australia; (c) the diffusion mechanism in mature greenhouse-propagated tissue is an accurate representation of the mechanism operating in mature field cane; (d) present evidence does not exclude the operation of a sugar-carrier complex in which the carrier may be a rate-limiting factor.

These conclusions are based in part on the sugar accumulation mechanism developed in Australia during the 1960's. It was shown that sucrose storage involves active transport with the first step being the hydrolysis of sucrose to glucose and fructose $(20,27)$. The latter pass through the cell wall into a metabolic compartment where sucrose phosphate is formed and transported 
across the vacuolar membrane to be stored as sucrose $(19,22)$. When immersed in water, it was thought that sucrose diffused outward via a simple diffusion mechanism (14) the rate of which depends upon the concentration of stored sugar (18).

In essence, diffusion to the external medium can be depicted in three stages: (a) Efflux exceeding accumulation; (b) efflux equaling accumulation; and (c) accumulation exceeding efflux. During the latter stage sucrose is being taken up by the tissue faster than it diffuses; hence, the sucrose concentration of the external solution decreases. During the present investigations the three phases of sugar diffusion were evident in both mature and immature storage tissue. The data further conformed with the operation of discrete sugar storage mechanisms in the two tissues (15). Immature tissue achieved an earlier efflux peak of lower magnitude than mature storage tissue. These results are consistent with Glasziou's observations

TABLE 4.-Effect of boron on the rate of sucrose diffusion from malure sugarcane storage tissue ${ }^{1}$

\begin{tabular}{lcccc}
\hline \multirow{2}{*}{ Bathing medium } & \multicolumn{4}{c}{ Percent of total storage sucrose at hour- } \\
\cline { 2 - 5 } & 0 & 2 & 4 & 12 \\
\hline Distilled water & 0 & 1.58 & 2.09 & 2.23 \\
Boric acid $\left(5 \times 10^{-7} \mathrm{M}\right)$ & 0 & 1.76 & 2.24 & 2.74 \\
Boric acid $\left(5 \times 10^{-3} \mathrm{M}\right)$ & 0 & 2.49 & 3.19 & 3.67 \\
\hline
\end{tabular}

${ }^{1}$ Mean values for duplicate flasks.

that maturation of storage tissue is accompanied by an increase in the rate of efflux (11) and a reduction in the rate of accumulation $(1,11,12)$.

Hatch et al. (17) have shown that Tris buffer inhibits acid invertase, and Sacher et al. (27) found that, as a consequence, it inhibits sucrose uptake. The effects of Tris on sugar diffusion, shown in table 2 and figure 4, are consistent with this view. Presumably, the differential effects of Tris buffer on mature and immature tissues can be traced to the declining quantities of acid invertase found in aging joints $(17,18)$.

Major importance is attached to the initial rapid phase of sucrose diffusion. Under in vitro conditions, of finite tissue volume, it provided for rapid depletion of outer space sugar (including sugar dissolved in the cell wall water). A similar mechanism operating in vivo, that is, with practically unlimited tissue volume, might contribute a continual sucrose flow within several categories of sugar movement: (a) Via cell walls or conducting phloem to areas of rapid sugar utilization; (b) toward the storage vacuole as a means of "buffering" or countering sugar deficits in the inner space, as suggested by Glasziou (15); and (c) efflux from mature stalks via fissures created by physiological or mechanical means. The latter would facilitate 
sucrose losses during postharvest washing operations (25). Diffusion might also contribute to sucrose losses from harvested cane in open-air storage, particularly during periods of heavy rainfall.

Inhibitor-induced changes in the shape of diffusion curves may give added information about the diffusion mechanism. This concept and its limitations as applied to sugar transport profiles is treated at length by Canny (6). The present effects of cycloheximide (fig. 6) and DNP (table 3) suggest that vacuolar or inner space sugar will also diffuse to the external medium when the active accumulation process is curtailed. In the instance of cycloheximide a continued efflux of sucrose from inhibitor-treated tissue was recorded during the period when sugar reentry normally exceeds diffusion. As an inhibitor of protein synthesis (8) the effect of cycloheximide is best explained by action against neutral invertase. An enormous increase in diffusion rate was produced by DNP. By blocking the respiratory production of ATP $(16,23)$, DNP presumably imposed restrictions against the energy-dependent phase of active sugar accumulation. An important implication here is that diffusion will provide a means of sucrose "leakage" whenever the active accumulation process is disrupted, whether by artificial or natural means.

Some workers contend that physiological data gathered with greenhouse plants has only limited applicability to field cane. This is quite true of certain cultural information, but it is probably not true of biochemical mechanisms fundamental to plant growth and development. The present data indicate that sugar diffusion operates by a comparable mechanism regardless of propagation conditions for the storage tissue. The differences in sugar reentry rates observed with immature tissue (fig. $5, \mathrm{~B}$ ) possibly relate to the greater consistency of water and nitrogen supplies afforded in the greenhouse. Under these conditions, greenhouse plants experience a continuously high level of growth activity and sugar utilization in the expanding internodes.

The possibility that boron may participate in sugar-movement mechanisms has been recognized for nearly 2 decades. Sisler et al. (28) reported that ${ }^{14} \mathrm{C}$-labeled photosynthate was translocated more readily by boronsufficient tomato plants than boron-deficient plants. Gauch and Dugger (10) observed that minute quantities of boron hastened the absorption and movement of applied sucrose, and proposed that a readily-ionizable, sugarborate complex had formed which passed more readily through cell membranes than free sugar. Zittle (30) described a boratc ion reaction with $\mathrm{OH}$ rich compounds having two $\mathrm{OH}$ groups in the cis position. Although sucrose does not fulfill this requirement, Gauch and Dugger suggested a borate union involving the trans-1,2-diol groups, with the borate ion ultimately being set free at the inner surface of the cell membrane. This hypothesis is consistent with Epstein's (9) concept of active ion-carrier movement across 
root membranes. While the present data are inadequate to draw firm conclusions, the possibility that boron may participate in sugar diffusion in sugarcane storage tissue is sufficiently' strengthened to justify further investigation.

\section{SUMMARY}

Sugar diffusion studies were performed with sugarcane stem tissues bathed in distilled water, Tris buffer, and aqueous solutions of various chemical additives. Rind-free tissue slices were prepared with mature and immature internodes from ficld-grown sugarcane, and from plants propagated in the greenhouse with constant water and nitrogen supply.

Sucrose diffusion rates were of sufficient magnitude to have physiological, and possibly economic, significance. Sugar movement to the external media conformed with the operation of an active accumulation mechanism as described by workers in Australia. Initial cfflux was rapid up to about 4 hours, achieving a maximum external sugar concentration between 8 and 12 hours, followed by depletion of sucrose in the bathing medium. The depletion phase was attributed to reentry of sugar into the tissue slices rather than inversion. Inclusion of cycloheximide and 2,4-dinitrophenol in the bathing medium permitted a continuing efflux of sucrose amounting to 5- to 10-fold increases over that obtained with distilled water. Actinomycin D produced no appreciable effect on initial efflux rate. 6-methyl purine appeared to block reentry of exited sugar without causing leakage of vacuolar sucrose.

Diffusion patterns for mature storage tissue suggested that a single mechanism is operative for field- and greenhouse-reared cane. Tris buffer did not affect sucrose diffusion from mature tissue, but increased diffusion from immature storage tissue owing to an apparent inhibition of acid invertase. In general, sucrose diffusion was of greater magnitude from mature than immature tissue preparations, and reducing sugars diffused at a much lower rate which seldom exceeded 10 percent of the sucrose level. Addition of borate to the bathing medium appreciably increased the quantity of exiting sugar without altering the shape of the diffusion curve. The existence of a sugar-borate carrier system operating in the passage of cellular membranes is suggested.

Physiological roles of a diffusible sugar pool in the intercellular spaces or dissolved in cell-wall water are evaluated. The potential significance of diffusion in promoting sucrose losses from stalks mechanically injured during harvest and post-harvest operations is also mentioned.

\section{RESUMEN}

Se estudió la difusión de los azúcares en los tejidos del tallo de caña de azúcar bañada en agua destilada, en el amortiguador Tris y en soluciones acuosas de varios compuestos químicos. 
Se prepararon secciones del tejido sin la corteza, utilizando entrenudos maduros y tiernos de caña cultivada en el campo, y de caf̂́a cultivada en el invernadero con un suministro constante de agua y nitrógeno.

La razón de difusión de la sacarosa fue de suficiente magnitud como para tener un significado en el aspecto fisiológico y posiblemente en el económico. El movimiento del azúcar hacia la solución externa concordó con la acción de un mecanismo de acumulación activa según ha sido descrito previamente por otros investigadores en Australia. El flujo fue rápido hasta las primeras 4 horas, alcanzando una concentración máxima de azúcar en la solución externa entre las 8 y 12 horas, seguida luego de una disminución de la sacarosa en la solución. Esta fase de la disminución se atribuyó a la reintegración del azúcar al tejido antes que a su inversión. La adición de cicloheximida y 2,4-dinitrofenol a la solución permitió un flujo continuo de aracarosa 5 a 10 veces mayor que el que se obtuvo con agua destilada. La actinomicina $D$ no tuvo un efecto apreciable en la tasa inicial del flujo. La 6-metil-purina pareció bloquear el reintegro del azúcar al tejido sin que se escapara la sacarosa almacenada en la vacuola.

Los patrones de difusión para el tejido reservante maduro sugirieron que se trata de un mecanismo único que opera tanto en la caña cultivada en el campo como en la caña de invernadero. El amortiguador Tris no afectó la difusión de la sacarosa del tejido pero sí produjo un aumento en el tejido tierno debido a una inhibición aparente de la invertasa ácida. En general, la difusión de la sacarosa fue mayor en las preparaciones hechas con tejido maduro que con tejido tierno y la difusión de los azúcares reductores fue a un grado mucho menor, que raras veces excedió un 10 por ciento del nivel de sacarosa. La presencia de borato en la solución aumentó grandemente la cantidad de azúcar que salió del tejido sin alterar la forma de la curva de difusión. Se sugiere la existencia de un sistema transportador de azticar-borato que opera en el transporte a través de membranas celulares.

Se evalúa el papel fisiológico que desempeñaría una reserva de azúcar difundible en los espacios intercelulares o disuelta en el agua de la pared celular. También se menciona el posible significado de la difusión al ésta promover pérdidas de sacarosa en los tallos que han sido afectados por las operaciones mécanicas durante y después de la cosecha.

\section{LITERATURE CITED}

1. Bieleski, R. L., Studies on the physiology of sugar cane. Doctoral thesis, University of Sydney, 1958. (Not seen)

2. - The physiology of sugarcane. III. Characteristics of sugar uptake in slices of mature and immature storage tissue, Aust. J. Biol. Sci. 13: 203-20, 1960.

3. - The physiology of sugar cane. IV. Effects of inhibitors on sugar accumulation in storage tissue slices, Aust. J. Biol. Sci. 13: 221-31, 1960.

4. - The physiology of sugar cane. V. Kinetics of sugar accumulation, Aust. J. Biol. Sci. 15: 429-44, 1862.

5. Brovchenko, M. I., Hydrolysis of sucrose in the free space of leaf tissues, and the localization of invertase, Fisiol. Rast. 17(1): 31-9, 1970. (Chem. Abs. 73: 80-973B, 1970.)

6. Canny, M. J., Translocation: Mechanisms and kinetics, Ann. Rev. Plant Physiol. $22: 237-60,1971$.

7. Cardini, C. E., Leloir, L. F., and Chiriboga, J., The biosynthesis of sucrose, J. Biol. Chem. 214: 149-55, 1955.

8. Colombo, B., Felicetti, L., and Baglioni, C., Inhibition of protein synthesis by cycloheximide in rabbit reticulocytes, Biochem. Biophys. Res. Comm. 18(3): $389-96,1965$. 
9. Epstein, E., Passive permeation and active transport of ions in plant roots, Plant Physiol. 31 : 529-35, 1956.

10. Gauch, H. G., and Dugger, W. M., The role of boron in the translocation of sucrose, Plant Physiol. 28: 457-66, 1953.

11. Glasziou, K. T., Accumulation and transformation of sugars in sugar cane stalks, Plant Physiol. 35: 895-901, 1960.

12. - Accumulation and transformation of sugars in sugar cane. Origin of glucose and fructose in the inner space, Plant Physiol. 36: 175-79, 1961.

13. - Accumulation and translocation of sugars in sugar cane stalks: Mechanism of inversion of sucrose in the inner space, Nature 193: 1100, 1962.

14. - Hatch, M. D., and Sacher, J. A., Accumulation and transformation of sugars in sugar cane storage tissue, Proc. Int. Soc. Sugar Cane Technol. 11: 334-8, 1962.

15. - Personal communication with A. G. Alexander, January 1971.

16. Hacket, D. P., Respiratory inhibitors, Encyclopedia of Plant Physiology 2: 23-41, 1960.

17. Hatch, M. D., Sacher, J. A., and Glasziou, K. T., Sugar accumulation cycle in sugar cane. I. Studies on enzymes of the cycle, Plant Physiol. 38: 338-43, 1963.

18. - and Glasziou, K. T., Sugar accumulation cycle in sugar cane. II. Relationship of invertase activity to sugar content and growth rate in storage tissue of plants grown in controlled environments, Plant Physiol. 38: 344-8, 1963.

19. - - Sugar accumulation by sugar-cane storage tissue: The role of sucrose phosphate, Biochem. J. 93: 521-6, 1964.

20. Hawker, J. S., and Hatch. M. D., Mechanism of sugar storage by mature stem tissue of sugarcane, Physiol. Plant 18: 444-53, 1965.

21. Hawker, J. S., The sugar content of cell walls and intercellular spaces in sugarcane stems and its relation to sugar transport, Aust. J. Biol. Sci. 18: 959-69, 1965.

22. —, and Hatch, M. D., A specific sucrose phosphatase from plant tissues, Biochem, J. 99: 102-07, 1966.

23. Hochster, R. M., Metabolic Inhibitors, Academic Press, N. Y., 2: 311-436, 1963.

24. Höber, R., Physical Chemistry of Cells and Tissues, Churchill publishers, London, 1947.

25. Montalvo-Zapata, R., Suazo-Rodriguez, P., and Alexander, A. G., Sugar losses during the postharvest washing of sugarcane (research note), J. Agr. Univ. P.R. 56(2): 181-2.

26. Roe, J. R., A colorimetric method for the determination of fructose in blood and urine, J. Biol. Chem. 107: 15-22, 1934.

27. Sacher, J. A., Hatch, M. D., and Glasziou, K. T., Sugar accumulation cycle in sugarcane. III. Physical and metabolic aspects of cycle in immature storage tissues, Plant Physiol. 38(3): 348-54, 1963.

28. Sisler, R. M., Dugger, W. M., and Gauch, H. C., The role of boron in the translocation of organic compounds in plants, Plant Physiol. 31: 11-17, 1056.

29. Sumner, J. B., Dinitrosalicylic-acid: A reagent for estimation of sugar in norma and diabetic urine, J. Biol. Chem. 47: 5-9, 1921.

30. Zittle, C. A., Reactions of borate with substances of biological interest, Adv. in Enzymol. 12: 493-527, 1951. 